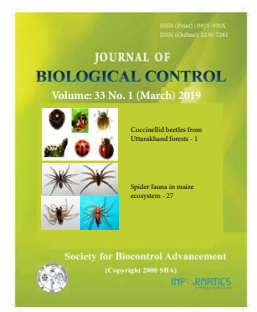

Research Article

\title{
A chemically sulfated derivative galactomannan from Adenanthera pavonina seeds elicits defense-related responses in cowpea and confers protection against Colletotrichum gloeosporioides
}

\author{
ANNA L. N. VARELA ${ }^{1}$, ILKA M. VASCONCELOS ${ }^{1}$, RODOLPHO G. G. SILVA ${ }^{1}$, HUDSON F. N. MOURA ${ }^{1}$, THIAGO \\ F. MARTINS ${ }^{1}$, DARCY M. F. GONDIM ${ }^{1,2}$, NAGILA M. P. S. RICARDO ${ }^{3}$, FRANCISCO C. O. FREIRE ${ }^{4}$ and JOSE T. A. \\ OLIVEIRA $^{1^{*}}$ \\ ${ }^{1}$ Department of Biochemistry, Science Center, Federal University of Ceara, Fortaleza- CE, 60020-181, Brazil \\ ${ }^{2}$ University of Fortaleza (UNIFOR), Fortaleza, Ceara, Brazil \\ ${ }^{3}$ Department of Chemistry, Science Center, Federal University of Ceara, Fortaleza- CE, 60020-181, Brazil \\ ${ }^{4}$ Brazilian Enterprise for Agricultural Research (EMBRAPA-CNPAT), Fortaleza, Ceara, Brazil \\ "Corresponding author E-mail: jtaolive@ufc.br
}

\begin{abstract}
This work was conducted to assess whether or not a natural occurring polysaccharide from Adenanthera pavonina seeds (PLSAp) and its chemically sulfated derivative galactomannan (SPLSAp), which did not act as fungicides, induce defense proteins and protect a susceptible cowpea (Vigna unguiculata) genotype (BR3-Tracuateua) against the phytopathogenic fungus Colletotrichum gloeosporioides. Twelve-day-old plants were sprayed to run-off with PLSAp or SPLSAp, both at 100 and $200 \mathrm{mg} \mathrm{L}^{-1}$, dissolved in $0.01 \%$ Triton X-100, which served as control. The primary leaves were collected at $0,6,12,24$, and $48 \mathrm{~h}$ after the carbohydrate treatments and the activities of guaiacol peroxidase (POX), $\beta$-1,3-glucanase ( $\beta \mathrm{GLU}$ ), and chitinase (CHI) were determined to verify the ability of the studied galactomannans to induce alterations in their kinetics. In addition, the primary leaves of a plant group previously sprayed with SPLSAp and $6 \mathrm{~h}$ later inoculated with $C$. gloeosporioides were collected at $0,6,12,24$, and $48 \mathrm{~h}$ after the polysaccharide treatment, the enzyme activities measured, and the severity of the fungal disease evaluated. SPLSAp induced more prominently POX, $\beta$ GLU, and CHI activity than PLSAp. Importantly, the combined treatment of SPLSAp and C. gloeosporioides was even more effective as enzyme inductor than SPLSAp alone, and the necrotic lesions of the anthracnose disease caused by the fungus were much less severe compared to control plants. The results indicate that SPLSAp induces plant defense proteins and increases the cowpea tolerance to $C$. gloeosporioides. These findings indicate that SPLSAp merits further investigation as a promising alternative or a supplemental environmentally friendly protector agent against anthracnose.
\end{abstract}

KEY WORDS: Colletotrichum gloeosporioides, cowpea, defense response, sulfated galactomannan, Vigna unguiculata

(Article chronicle: Received: 09-11-2018; Revised: 11-03-2019; Accepted: 15-03-2019)

\section{INTRODUCTION}

A wide range of pathogens can attack and affect cowpea (Vigna unguiculata [L.] Walp.) productivity and quality. Due to its great importance as a nutritious foodstuff, particularly in the arid and semi-arid regions of the world, and the crescent demand for food, improved agronomic practices are required to increase cowpea output. These include the use of natural products to combat pathogens and pests in place of toxic pesticides that are harmful to humans and other living things, and pollute the environment (Mostafalou and Abdollahi, 2013). To reduce these damaging effects, considerable efforts have been made to develop alternative protection strategies. Plants can defend themselves against pathogen attacks by triggering defense reactions that include physical, chemical, and enzymatic responses. Therefore, induction of plant defense responses based on the use of environmentally friendly elicitors constitutes a good strategy. Induction of plant defense mechanisms can be triggered by elicitors from the pathogen (exogenous elicitors) or from the plant itself (endogenous elicitors) (Thakur and Sohal, 2013). Once these elicitors are recognized by plant cells through interaction with specific receptors on plasma membranes the elicitor-receptor complexes formed transmit intracellular signals that will provoke the differential expression of plant defense related genes, involved with reactive oxygen species (ROS) generation, cell wall reinforcement, biosynthesis of 
secondary metabolites, lytic enzymes and pathogenesis related proteins (PR-proteins), amongst other defensive compounds (Mishra et al., 2012; Thakur and Sohal, 2013). Many types of elicitors of plant defense have been characterized such as fungal cell wall fragments, oligosaccharides, lipopolysaccharides, peptidoglycans, glycoproteins, and proteinogenic amino acids (Mishra et al., 2012). Therefore, elicitor compounds from various biological sources such as plants, bacteria, oomycetes, and fungi as well as their potential for crop protection have been extensively investigated (Wiesel et al., 2014)

Diverse biological activities have been attributed to natural and chemically sulfated derivative polysaccharides such as anticoagulation, anti-thrombotic, antiviral, antioxidant, antitumor, anti-inflammatory and immunomodulatory, antiatherosclerotic, anti-adhesive, antipeptic, antiulcerogenic, antilipidemic, and inhibition of microbial growth (Raposo et al., 2013; Caputo et al., 2019). In addition, it has been reported that sulfation of polysaccharides, which can turn the molecules more negatively charged and alter their three-dimensional structure, are important to induce systemic resistance in plants and increased resistance responses against pathogens (Caillot et al., 2012; Trouvelot et al., 2014). In consonance with the search for new environmentally friendly elicitors, which activate chemical defense in plants, the aim of this current work was to assess whether or not a natural galactomannan isolated from Adenanthera pavonina seeds (PLSAp) and its chemically sulfated derivative galactomannan (SPLSAp) induce plant defense-related proteins in a susceptible cowpea genotype (BR3-Tracuateua) and confer protection against Colletotrichum gloeosporioides disease. A. pavonina (Fabaceae), popularly known as Carolina, dragon's eye, and red-bead tree, is common in Brazil, where it has been used for ornamental purposes, forestation, and shading. Importantly, it was scientifically demonstrated that the bark and seeds of $A$. pavonina contain compounds that are antioxidant, anti-inflammatory, analgesic, antihypertensive, anthelmintic, antibacterial, antifungal, and antiviral (Ara et al., 2010; Soares et al., 2012; Godoi et al., 2014).

\section{MATERIALS AND METHODS}

\section{Materials}

Cowpea (Vigna ungruiculata (L.) Walp.) genotype BR3-Tracuateua (thereafter referred as BR-3) seeds were provided by the Empresa Brasileira de Pesquisa Agropecuaria (Brazilian Enterprise for Agricultural Research), EMBRAPA - Meio Norte (Piaui State- Brazil) and surface sterilized with sodium hypochlorite solution $(0.05 \%[\mathrm{v} / \mathrm{v}]$ active chlorine) for $3 \mathrm{~min}$, rinsed thoroughly and soaked in distilled water for 10 minutes. Seeds were sown in 0.5 -L pots containing $300 \mathrm{~g}$ autoclaved $\left(120^{\circ} \mathrm{C}, 1.5 \times 10^{5} \mathrm{~Pa}\right.$, $30 \mathrm{~min}$ ) river sand previously washed thoroughly with tap water. After planting, the pots were kept in a greenhouse where average temperature varied from $24{ }^{\circ} \mathrm{C}$ (night) to 35 ${ }^{\circ} \mathrm{C}$ (day) and Relative Humidity (RH) varied from $55 \%$ (day) to $80 \%$ (night). The pots were exposed to natural light with Photosynthetic Photon Flux Density (PPFD) varying from 300-650 $\mu$ moles $\mathrm{m}^{-2} \mathrm{~s}$ el (190SA quantum sensor, LI-COR, USA) and $12 \mathrm{~h}$ photoperiod. During the first 3 days after sowing, irrigation was done daily with $50 \mathrm{~mL}$ per pot of $10 \mathrm{x}$ diluted proper nutrient solution (Silveira et al., 2001) and, thereafter, irrigated with the undiluted solution.

The naturally occurring galactomannans from Adenanthera pavonina seeds (PLSAp) and its chemically sulfated derivative polysaccharides (SPLS $A p$ ) were prepared in the Laboratory of Polymer at Federal University of Ceara, Brazil. Seeds were first boiled in distilled water for 20-30 min and kept at room temperature until the seeds doubled their original size. Next the hulls and germs were removed and the endosperms reserved. The galactomannan was extracted from the seed endosperms using hot $\left(85-100{ }^{\circ} \mathrm{C}\right)$ distilled water for $3 \mathrm{~h}$. The gelatinous material obtained was passed through nylon net, filtered through celite, and lyophilized (Vieira et al., 2007). To prepare (Godoi et al., 2014) the chemically sulfated derivative galactomannan (SPLSAp), the lyophilized material was swollen in pyridine:N,N-dimethylformamide $(50: 10, \mathrm{v} / \mathrm{v})$ at $25{ }^{\circ} \mathrm{C}$ under stirring until a finely dispersed suspension was obtained. After cooling at $4{ }^{\circ} \mathrm{C}$, chlorosulfonic acid was slowly added and the suspension left under stirring for 24 hours. Next, saturated aqueous $\mathrm{NaHCO}_{3}$ was added to neutralize the material, which was dialyzed (dialysis tube with $12 \mathrm{kDa}$ cutoff) for $120 \mathrm{~h}$ against distilled water to allow lyofilization of SPLSAp. SPLSAp presents $13.6 \%$ sulfate content percentage (S\%), 1.21 degree of sulfation (DS), which represents the average number of sulfates on monomer residues and $7.0 \times 10^{5} \mathrm{~g} \mathrm{~mol}^{-1}$ molecular mass (Godoi et al., 2014).

Colletotrichum gloeosporioides stock cultures were from the Laboratory of Phytopathology of EMBRAPA Tropical Agroindustry (CNPAT), Fortaleza, CE, Brazil, maintained on Potato-Dextrose-Agar (PDA) and incubated at $28 \pm 1^{\circ} \mathrm{C}$, with a photoperiod of $16 \mathrm{~h} \mathrm{light} / 8 \mathrm{~h}$ dark, for 7 days for mass-production. Fourteen-day-old cultures of $C$. gloeosporioides were flooded with sterile distilled water, scraped with a sterile glass rod, and the slurry obtained filtered through a four-layers of sterile cheesecloth to remove fungal mycelia and other debris. The spore suspension (filtrate) was counting in a Neubauer chamber under a microscope (Olympus System BX60) and diluted with sterile distilled water to $4 \times 10^{5}$ spores $\mathrm{mL}^{-1}$.

\section{Treatment of cowpea with PLSAp and SPLSAp}

To assess the ability of the studied galactomannans in 
inducing plant defense responses, visually healthy cowpea plantlets were selected twelve days after sowing and the whole canopy of a group of plants was sprayed (100 or $200 \mathrm{mg} \mathrm{L}^{-1}$ ) to run-off with PLSAp and other group with SPLSAp, both prepared in $0.01 \%(\mathrm{v} / \mathrm{v})$ Triton X-100, which was used to spray a third group of control plants. Plants were placed in a highly humid chamber $\left(\mathrm{RH}>80 \%, 22 \pm 1{ }^{\circ} \mathrm{C}\right)$ overnight, after which they were submitted to a $12 \mathrm{~h}$ light/12 h dark photoperiod. The primary leaves were collected at $0,6,12$, 24 , and $48 \mathrm{~h}$ after the carbohydrate treatments, immediately conditioned in plastic bags, and kept at $-85^{\circ} \mathrm{C}$ until analyses. These consisted in determining the alterations on the kinetic of the enzyme activity of guaiacol peroxidase (POX), $\beta$-1,3-glucanase ( $\beta$ GLU), and chitinase ( $\mathrm{CHI})$, taken as plant defense-related proteins and used as molecular markers of the ability of the studied galactomannans in inducing plant defense responses. To evaluate whether SPLSAp confer any protection to the susceptible cowpea genotype against the studied fungus, a plant group was previously sprayed with SPLSAp and other with $0.01 \%$ (v/v) Triton X-100 (control), as above. Six hours later they were inoculated with $C$. gloeosporioides by applying microdrops $(100 \mu \mathrm{L})$ of the fungus suspension $\left(4 \times 10^{5}\right.$ spores $\left.\mathrm{mL}^{-1}\right)$ on the adaxial cowpea leaf blade. These plant groups were placed in a highly humid chamber $\left(\mathrm{RH}>80 \%, 22 \pm 1^{\circ} \mathrm{C}\right)$ overnight, after which they were submitted to a photoperiod of $12 \mathrm{~h}$ light/12h dark regime, $\mathrm{RH}$ kept $>60 \%$, and temperature at $24 \pm 1{ }^{\circ} \mathrm{C}$. The appearance of any disease (anthracnose) signal in leaves was evaluated 12 days after $C$. gloeosporioides inoculation and severity determined according to the rating scale proposed by Suryanto et al. (2014): $0=$ no symptom; $1=0$ to $20 \% ; 2=20$ to $40 \% ; 3=40$ to $60 \% ; 4=60$ to $80 \%$; and $5=80$ to $100 \%$ disease severity range. The enzyme activity of ascorbate peroxidase (APX), POX, $\beta$ GLU, and CHI were also evaluated at $0,6,12,24$, and $48 \mathrm{~h}$ after the carbohydrate treatments. Every treatment was conducted in triplicates, each consisting of six plants in individual pots. The experiment was thrice repeated under the same above conditions.

\section{Preparation of enzyme extracts from primary leaves of cowpea}

The extraction of soluble proteins was performed by macerating the primary cowpea leaves collected from each experiment, and for each time point, with $0.05 \mathrm{M}$ sodium acetate buffer ( $\mathrm{pH}$ 5.2) containing $0.50 \mathrm{M} \mathrm{NaCl}$ (in a relation of $1 \mathrm{~g}$ of leaves per $5 \mathrm{~mL}$ of buffer), for $15 \mathrm{~min}$, using a pre-chilled mortar and pestle kept on ice bath. The suspension was filtered through one layer of cheesecloth and centrifuged at $10,000 \mathrm{~g}$ for $5 \mathrm{~min}$ at $4{ }^{\circ} \mathrm{C}$. The supernatant was recovered and dialyzed against the extracting buffer for $24 \mathrm{~h}$ (six changes with ten times the supernatant volume, at a $12-\mathrm{h}$ interval) at $4{ }^{\circ} \mathrm{C}$. The dialyzed leaf extract (thereafter DLE) obtained from each treatment and time point was utilized for protein content and enzymatic activity measurements.

\section{Protein content determination}

Total soluble protein content of DLE was quantified spectrophotometrically (Bradford, 1976). To $100 \mu \mathrm{L}$ DLE $2.5 \mathrm{~mL}$ Bradford reagent were added and $10 \mathrm{~min}$ later the absorbance readings of triplicates were measured at $595 \mathrm{~nm}$. The protein content was calculated on the base of a standard curve built with known concentrations of Bovine Serum Albumin (BSA).

\section{Enzyme assays}

The enzymatic activities of DLE were conducted using an amount of protein in the linear range of the assays. Three enzymatic independent assays for each time point were carried out using three independent DLE samples, each one obtained from 3 plants.

POX activity was measured as previously described (Urbanek et al., 1991). A $10 \mu \mathrm{L}$ aliquot of DLE was added to $990 \mu \mathrm{L}$ of $50 \mathrm{mM}$ sodium acetate buffer ( $\mathrm{pH} 5.2), 500 \mu \mathrm{L}$ of $60 \mathrm{mM} \mathrm{H}_{2} \mathrm{O}_{2}$, and $500 \mu \mathrm{L} 20 \mathrm{mM}$ guaiacol (Sigma Chemical Company). The reaction mixture was incubated at $30^{\circ} \mathrm{C}$ and the increase in absorbance at $480 \mathrm{~nm}$ recorded during $2 \mathrm{~min}$ at $20 \mathrm{~s}$ intervals. The variation of 1.0 absorbance unit $\mathrm{mL}^{-1} \min ^{-1}\left(\Delta \mathrm{Abs}_{480 \mathrm{~nm}} \mathrm{~mL}^{-1} \mathrm{~min}^{-1}\right)$ was taken as one POX activity (1 AU), which was expressed per gram of leaf fresh $\operatorname{mass}\left(\mathrm{AU} \mathrm{g}^{-1} \mathrm{FM}\right)$.

$\beta$ GLU activity was measured by determining the amount of glucose liberated from laminarin (Sigma-Aldrich) used as substrate (Boller, 1992). Laminarin was dissolved in ultrapure water (Milli-Q grade), heated to $60{ }^{\circ} \mathrm{C}$ for $10 \mathrm{~min}$, and dialyzed exhaustively against ultrapure water (Milli-Q) for removal of free glucose. The assay was conducted with $0.1 \mathrm{~mL}$ of sample incubated with $0.9 \mathrm{~mL}$ of laminarin $\left(2.0 \mathrm{mg} \mathrm{mL}^{-1}\right)$ at $50{ }^{\circ} \mathrm{C}$ for $30 \mathrm{~min}$. After addition of the appropriate reagents to the reaction mixture, according to Boller (1992), absorbance readings were taken at $520 \mathrm{~nm}$. The quantity of glucose monomers released from laminarin was determined using a standard curve built with known amounts (42.2 to $1332.1 \mathrm{nM}$ ) of the corresponding sugar. $\beta$ GLU activity was expressed in nanokatal per gram fresh mass (nkat $\mathrm{g}^{-1} \mathrm{FM}$ ). One nkat is equivalent to $1.0 \mathrm{nmol}$ of D-glucose released $\mathrm{mL}^{-1} \mathrm{~s}^{-1}$.

CHI activity assay was conducted by measuring free N-acetyl-D-glucosamine (GlcNac) released from non-radioactive colloidal chitin (Molano et al., 1977) used as substrate by the combined hydrolytic action of cowpea chitinases and $\beta$-glucuronidase (Sigma-Aldrich), as previously described (Boller, 1992). GlcNac content was assessed using a colorimetric method (Reissig et al., 1995), at $585 \mathrm{~nm}$, based 
on a standard curve of commercial GlcNac (Sigma-Aldrich), ranging from $1 \times 10^{5}$ to $6 \times 10^{5} \mathrm{nM}$ concentrations. Both assays and the standard curve were developed in $50 \mathrm{mM}$ sodium acetate buffer ( $\mathrm{pH}$ 5.2). Chitinase activity was expressed in nanokatal per gram of leaf fresh mass (nkat g ${ }^{-1} \mathrm{FM}$ ). One nkat is equivalent to $1.0 \mathrm{nmol}$ of GlcNac released $\mathrm{mL}^{-1} \mathrm{~s}^{-1}$, at $37^{\circ} \mathrm{C}$.

APX activity was determined by adding $0.1 \mathrm{ml}$ of DLE to $0.8 \mathrm{ml}$ of a solution containing $0.5 \mathrm{mM} \mathrm{L}$-ascorbic acid diluted in $50 \mathrm{mM}$ potassium phosphate buffer, $\mathrm{pH} 6.0$, and $0.1 \mathrm{~mL}$ of $2 \mathrm{mM} \mathrm{H}_{2} \mathrm{O}_{2}$. The decrease in absorbance at $290 \mathrm{~nm}$ was monitored during $2 \mathrm{~min}$ at $20 \mathrm{~s}$ intervals at $30{ }^{\circ} \mathrm{C}$ (Koshiba, 1993; Nakano and Asada, 1981). One APX unit of activity (1 UA) was defined as the decrease of 1.0 absorbance unit $\mathrm{mL}^{-1} \mathrm{~min}^{-1}\left(\Delta \mathrm{Abs}_{290 \mathrm{~nm}} \mathrm{~mL}^{-1} \mathrm{~min}^{-1}\right)$ and expressed as UA per gram of leaf fresh mass (UA g $\left.{ }^{-1} \mathrm{FM}\right)$.

\section{Effect of SPLSAp on spore germination and vegetative growth of Colletotrichum gloeosporioides}

To assess whether SPLSAp have direct effects on both $C$. gloeosporioides spore germination and mycelial growth the methodology described by Freire et al. (2002), with modifications, was employed using 96-well ELISA plates. Inhibition of $C$. gloeosporioides spore germination was assayed as follow: in each well $100 \mu \mathrm{L}$ of Yeast Potato Dextrose (YPD) medium received $10 \mu \mathrm{L}$ of the spore suspension $\left(2 \times 10^{5}\right.$ cells $\left.\mathrm{mL}^{-1}\right)$, and $100 \mu \mathrm{L}$ SPLSAp at 100 and $200 \mathrm{mg} \mathrm{L}^{-1}$ concentrations in $0.01 \%(\mathrm{v} / \mathrm{v})$ Triton X-100, previously filtered through Millex GV $(0.22 \mu \mathrm{m})$ filter. After $48 \mathrm{~h}$, spores were examined under a light microscope (Olympus BX 60 Microscope System). A spore was considered germinated when the germination hypha length emitted corresponds to at least twice the length of the largest spore diameter (Paul et al., 1992). To examine the possible inhibitory effect on the fungus mycelial growth the spore suspension was added to the wells as above to allow spore germination and $12 \mathrm{~h}$ later SPLS $A p$ at 100 and $200 \mathrm{mg}$ $\mathrm{L}^{-1}$ concentrations in $0.01 \%(\mathrm{v} / \mathrm{v})$ Triton X-100, previously filtered through Millex GV $(0.22 \mu \mathrm{m})$ filter, were added. Absorbance readings were taken at $630 \mathrm{~nm}$ in an ELISA reader $\left(\mathrm{EL}_{\mathrm{X}} 800\right.$ Bio-Tek Instruments Inc.) at $12 \mathrm{~h}$ intervals, up to $96 \mathrm{~h}$ after the carbohydrate or control incubation with the fungus. Triton X-100 $(0.01 \%)$ was used as the negative and hydrogen peroxide $(100 \mathrm{mM})$ as the positive controls.

\section{Statistical analysis}

Data were subjected to one-way analysis of variance (ANOVA) and the significance of differences $(p \leq 0.05)$ between means evaluated using the Tukey's test.

\section{RESULTS AND DISCUSSION}

SPLSAP induced biochemical defense responses in cowpea
The chemically sulfated derivative galactomannan (SPLS $A p$ ) induced the PR-proteins POX, $\beta$ GLU, and CHI (Fig. 1) more prominently than the natural galactomannan (PLSAp) in comparison to the respective control plants. SPLS $A p$ treatment, at $100 \mathrm{mg} \mathrm{L}^{-1}$ increased $(\mathrm{p} \leq 0.05)$ POX activity at $6 \mathrm{~h}(\approx 97 \%)$ and $48 \mathrm{~h}(\approx 28 \%)$. Increased values $(\mathrm{p} \leq 0.05)$ of POX was also perceived after treatment with SPLSAp at $200 \mathrm{mg} \mathrm{L}^{-1}$ at $6 \mathrm{~h} \mathrm{( \approx 35 \% ),} 24 \mathrm{~h}(79.5 \%)$, and $48 \mathrm{~h}(\approx 81 \%)$ (Fig. 1). PLSAp also increased POX activity at $100 \mathrm{mg} \mathrm{L}^{-1}$, but only at $6 \mathrm{~h}(\approx 37 \%)$, whereas at $24 \mathrm{~h}$ and $48 \mathrm{~h}$ there were decreases in POX activity around $\approx 36 \%$ and $\approx 15 \%$, respectively. At $200 \mathrm{mg} \mathrm{L}^{-1}$, PLSAp also diminished POX activity at $12 \mathrm{~h}(\approx 25 \%), 24 \mathrm{~h}(36 \%)$, and $48 \mathrm{~h}(\approx 15 \%)$ post carbohydrate treatment.

Induction ( $\mathrm{p} \leq 0.05$ ) of $\beta$ GLU activity (Fig. 1$)$ by 100 $\mathrm{mg} \mathrm{L} \mathrm{L}^{-1}$ SPLS $A p$ was $\approx 136 \%, \approx 84 \%, 63.7 \%$, and $53.2 \%$, respectively, at $6 \mathrm{~h}, 12 \mathrm{~h}, 24 \mathrm{~h}$, and $48 \mathrm{~h}$ after the carbohydrate treatment over that of control plants. At $200 \mathrm{mg} \mathrm{L}^{-1}$, SPLS $A p$ augmented ( $\mathrm{p} \leq 0.05$ ) $\beta \mathrm{GLU}$ activity by $\approx 114 \%, \approx 108 \%$, $\approx 114 \%$, and $\approx 232 \%$, at $6 \mathrm{~h}, 12 \mathrm{~h}, 24 \mathrm{~h}$, and $48 \mathrm{~h}$ after SPLS $A p$ treatment, respectively, in relation to the respective control plants (Fig. 1). In contrast, PLSAp treatment exerted little effect on $\beta$ GLU activity.

Analysis of CHI activity profiles of cowpea plants sprayed with SPLSAp at $100 \mathrm{mg} \mathrm{L}^{-1}$ revealed significant $(\mathrm{p} \leq 0.05)$ increases in activity over those of control plants by around $92 \%, 100 \%$, and $207 \%$ at $12 \mathrm{~h}, 24 \mathrm{~h}$, and $48 \mathrm{~h}$, respectively. Application of SPLSAp at $200 \mathrm{mg} \mathrm{L}^{-1}$ also provoked increases of approximately $117 \%, 150 \%$, and $160 \%$ over those of the corresponding control plants at $12 \mathrm{~h}, 24$ $\mathrm{h}$, and $48 \mathrm{~h}$, respectively. In regard to PLSAp, the tendency of the CHI activity values was to be similar or below those of the respective control plants, from $6 \mathrm{~h}$ to $24 \mathrm{~h}$ after the treatment at both carbohydrate concentrations. However, at $48 \mathrm{~h}$, the CHI activity increased by $109 \%$ for $100 \mathrm{mg} \mathrm{L}^{-1}$ and $73 \%$ for $200 \mathrm{mg} \mathrm{L}^{-1}$. In summary, comparative examination of the enzyme kinetics tested within every time point studied after the carbohydrate treatments revealed overall higher activity $(\mathrm{p} \leq 0.05)$ in plants treated with SPLSA $A p$ over those treated with PLSAp (Fig. 1).

As SPLSAp promoted the highest increased in POX, $\beta \mathrm{GLU}$, and CHI compared to PLSAp (Fig. 1), the combined treatment in which the carbohydrate (100 or $200 \mathrm{mg} \mathrm{L}^{-1}$ concentrations) was applied and $6 \mathrm{~h}$ later the plants were inoculated with C. gloeosporioides was carried out exclusively using SPLSAp. Under these combined conditions, APX, an important antioxidant enzyme, increased in activity (Fig. 2), particularly at $24 \mathrm{~h}(354.5 \%$ and $354.5 \%$ applying 100 and $200 \mathrm{~g} \mathrm{~L}^{-1}$, respectively) and $48 \mathrm{~h}(318.2 \%$ and $190.9 \%$, applying 100 and $200 \mathrm{~g} \mathrm{~L}^{-1}$, respectively) after 


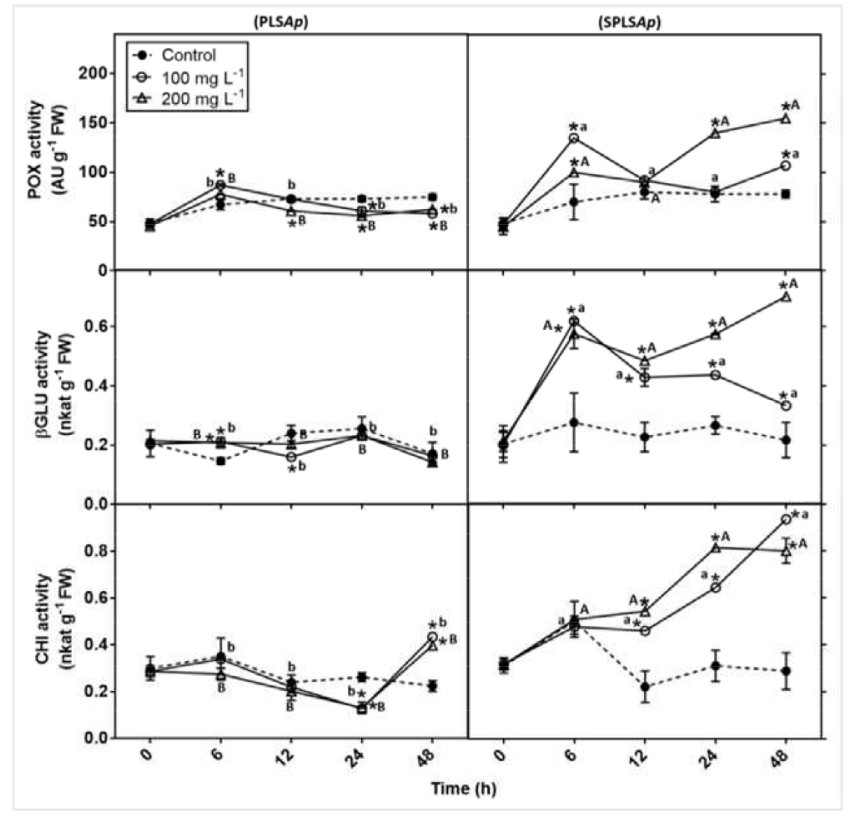

Fig. 1 Antioxidant enzymes and PR-protein kinetics in cowpea leaves treated with the natural (PLSAp) and chemically sulfated derivative galactomannan (SPLSAp). POX, $\beta G L U$, and $C H I$ activities were measured in the primary leaves sprayed until dripping ( $10 \mathrm{~mL}$ in each plant) with 100 and $200 \mathrm{mg} \mathrm{L}^{-1}$ of PLSAp or SPLS $A p$, prepared in $0.01 \%(v / v)$ Triton $X-100$, and evaluated $0,6,12,24$ and $48 \mathrm{~h}$ after the carbohydrate treatments. Control plants were sprayed with $0.01 \%$ (v/v) Triton X-100. Asterisk (*) indicates significant difference between the treatments and control. Lowercase letters represent significant differences $(p \leq 0.05)$ between the treatments with PLSAp and SPLSAp at $100 \mathrm{mg} \mathrm{L}^{-1}$ concentration and capital letters represent differences $(p \leq 0.05)$ between the treatments at $200 \mathrm{mg} \mathrm{L}^{-1}$, calculated by the Tukey's test at a confidence level of $5 \%(p \leq 0.05)$.

the SPLSAp treatment in relation to control plants treated with $0.01 \%(\mathrm{v} / \mathrm{v})$ Triton X-100. Higher significant increases $(\mathrm{p} \leq 0.05)$ in POX activity were also observed at $6 \mathrm{~h}(63 \%)$ after applying $100 \mathrm{~g} \mathrm{~L}^{-1}$ SPLSAp and after $12 \mathrm{~h}(95.2 \%$ and $125.2 \%$, applying 100 and $200 \mathrm{~g} \mathrm{~L}^{-1}$, respectively), $24 \mathrm{~h}(39.5 \%$ and $53.2 \%$, applying 100 and $200 \mathrm{~g} \mathrm{~L}^{-1}$, respectively), and $48 \mathrm{~h}$ (48.2\% and $85.4 \%$, applying 100 and $200 \mathrm{~g} \mathrm{~L}^{-1}$, respectively) in comparison with those of control plants (Fig. 2). Likewise, the plants previously treated with SPLSAp, at $100 \mathrm{mg} \mathrm{L}^{-1}$, followed $6 \mathrm{~h}$ later by $C$. gloeosporioides inoculation had also much higher $\beta$ GLU activity at $12 \mathrm{~h}(56.2 \%)$ and $48 \mathrm{~h}$ (93.3\%) after the SPLSAp treatment, over that of control plants (Fig. 2). Using SPLSAp at $200 \mathrm{mg} \mathrm{L}^{-1}$ concentration, followed $6 \mathrm{~h}$ later by $C$. gloeosporioides inoculation, the $\beta$ GLU activity significantly increased $(\mathrm{p} \leq 0.05)$ at $12 \mathrm{~h}$ (64.0\%), $24 \mathrm{~h}(55.3 \%)$, and $48 \mathrm{~h}(257.5 \%)$ in comparison with the control plants. CHI activity also increased $(\mathrm{p} \leq 0.05)$ in cowpea plants treated with SPLS $A p$, at 100 and $200 \mathrm{mg}$ $\mathrm{L}^{-1}$, followed by C. gloeosporioides inoculation (Fig. 2),

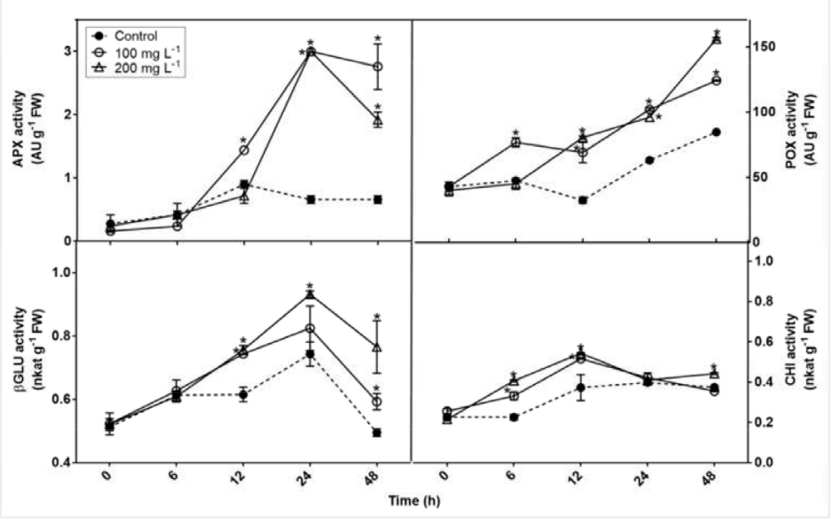

Fig. 2 Antioxidant enzymes and PR-protein kinetics in cowpea leaves treated with the chemically sulfated derivative galactomannan (SPLSAp) and $6 \mathrm{~h}$ later infected with Colletotrichum gloeosporioides. APX, POX, $\beta$ GLU, and CHI activities were measured in the primary leaves sprayed until dripping ( $10 \mathrm{~mL}$ in each plant) with 100 and $200 \mathrm{mg} \mathrm{L}^{-1}$ SPLSAp prepared in $0.01 \%$ (v/v) Triton $\mathrm{X}-100$ and $6 \mathrm{~h}$ later inoculated with $C$. gloeosporioides. Control plants were sprayed with $0.01 \%$ (v/v) Triton $\mathrm{X}-100$ and $6 \mathrm{~h}$ later inoculated with $C$. gloeosporioides. All samples were evaluated $0,6,12,24$, and $48 \mathrm{~h}$ after the carbohydrate treatments. Error bars indicate standard deviations. Asterisk (*) indicates significant difference between the treatment and control, calculated by the Tukey's test at a confidence level of $5 \%(p \leq 0.05)$.

particularly at $6 \mathrm{~h}\left(36.4 \%\right.$ and $77.3 \%$ for 100 and $200 \mathrm{mg} \mathrm{L}^{-1}$ SPLS $A p$ treatment, respectively) and $12 \mathrm{~h}(38.4 \%$ and $46 \%$ for 100 and $200 \mathrm{mg} \mathrm{L}^{-1}$ SPLSAp treatment, respectively) in relation to control plants. However, at $48 \mathrm{~h}$, only application of $200 \mathrm{mg} \mathrm{L}^{-1}$ SPLSA $p$ followed $6 \mathrm{~h}$ later by $C$. gloeosporioides inoculation showed a significant $(\mathrm{p} \leq 0.05)$ augment $(27.0 \%)$ respective to control plants. Importantly, it was not found any significant differences at $0 \mathrm{~h}$, for all enzyme activities tested between the SPLSAp-treated (100 and $200 \mathrm{mg} \mathrm{L}^{-1}$ ) and controls plants.

SPLSAp had no effect on the Colletotrichum gloeosporioides spore germination and mycelial growth

SPLSAp used as elicitor of plant defense in this study did not inhibit in vitro the $C$. gloeosporioides spore germination or mycelial growth (Fig. 3), at any of the concentrations (100 and $200 \mathrm{mg} \mathrm{L}^{-1}$ ) tested. This result indicates that SPLSAp has no direct antifungal action on C. gloeosporioides.

\section{SPLSAp protected cowpea leaves against Colletotrichum gloeosporioides infection}

The macroscopic examination of the primary leaves (Fig. 4a) inoculated only with the fungus (control) showed intense and numerous necrotic regions, 10 days after infection (Fig. 4a). Similarly, the primary leaves of cowpea plants previously treated with $100 \mathrm{mg} \mathrm{L}^{-1}$ SPLSAp and challenged with the fungus also showed necrotic lesions, 
a

b

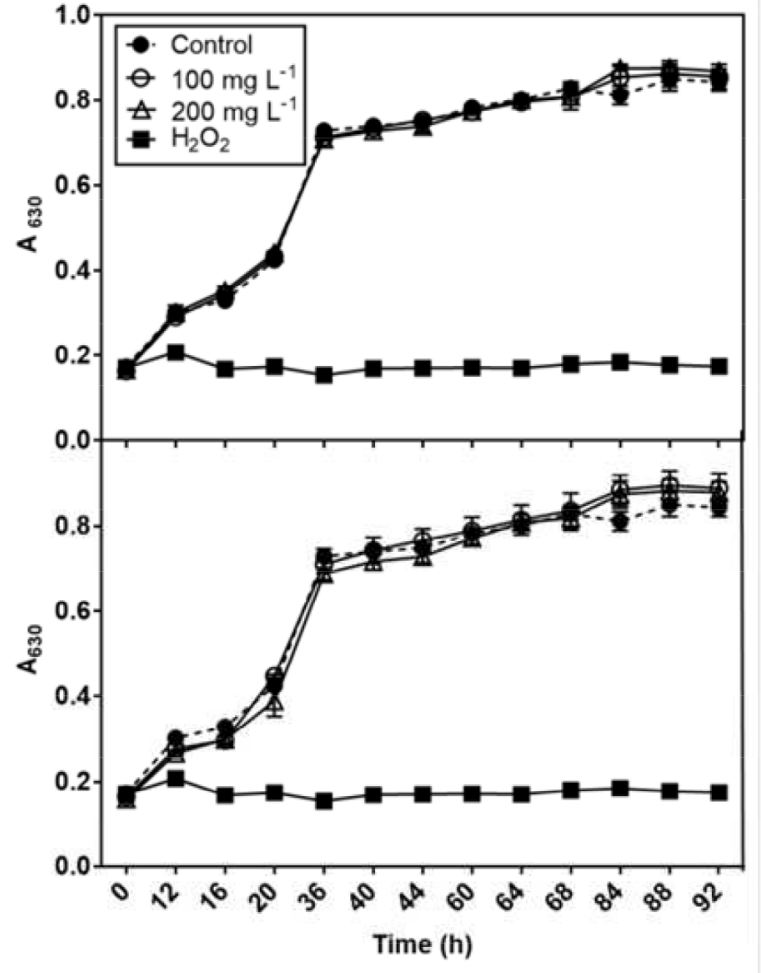

Fig. 3 Effect of SPLSAp on the germination (a) and growth (b) of Colletotrichum gloeosporioides. Control: $0.01 \%$ (v/v) Triton X-100; Treatments: 100 and $200 \mathrm{mg} \mathrm{L}^{-1}$ SPLSAp prepared in $0.01 \%(\mathrm{v} / \mathrm{v})$ Triton $\mathrm{X}-100$; Positive control: $100 \mathrm{mM} \mathrm{H} \mathrm{H}_{2}$ in ultrapure Milli-Q grade water. Vertical bars represent standard deviation. Each assay was carried out in triplicate.

but at much less extent (Fig. 4a) compared with the control cowpea plants although not quantitatively significantly different (Fig. 4b). However, the primary leaves of cowpea plants previously treated with $200 \mathrm{mg} \mathrm{L}^{-1}$ SPLSAp followed by inoculation with $C$. gloeosporioides spores presented very few necrotic lesions (4a) that characteristically possessed very low signal intensity and a lower $(\mathrm{p} \leq 0.05)$ disease severity (Fig. 4b) relative to the control plants solely inoculated with the fungus (Fig. 4b).

The use of natural and derivative inductors of resistance in plants for pest and pathogen management have become a promising option for triggering plant immunity and plant protection because they can reduce the residues left in fruits and vegetables after application of pesticides (Caillot et al., 2012; Llorens et al., 2017). In this present work we report that SPLSAp, a chemically sulfated carbohydrate derived from a natural galactomannan (PLSAp) from A. pavonina seeds, has potential to be used as a plant defense elicitor that protects cowpea (genotype BR-3) against $C$. gloeosporioides. Indeed, in parallel to induce changes in POX, $\beta \mathrm{GLU}$, and CHI (Fig. 1) SPLSAp mitigated the severity of the anthracnose symptoms caused by the hemibiotrophic fungus

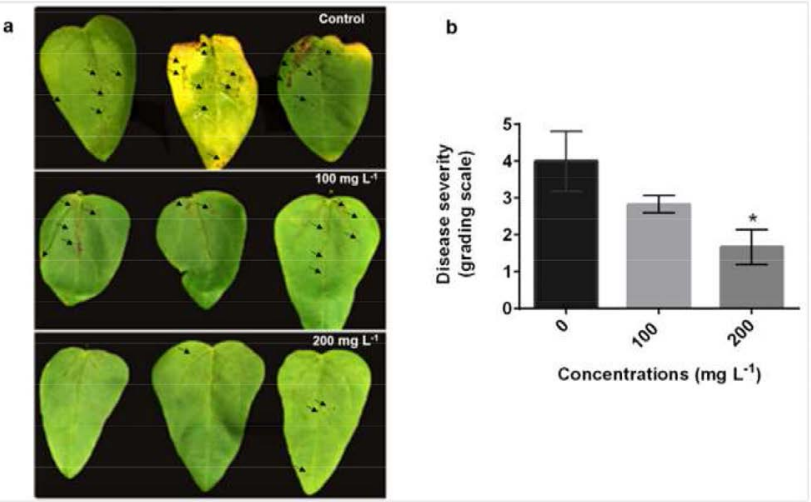

Fig. 4 Protective effect of SPLSAp on cowpea plants against Colletotrichum gloeosporioides evaluated 10 days after the fungus infection. (a) Average disease development and (b) disease severity in cowpea primary leaves infected with C. gloeosporioides. Plants were sprayed until dripping ( $10 \mathrm{~mL}$ in each plant) with 100 or $200 \mathrm{mg} \mathrm{L}^{-1} \mathrm{SPLS} A p$ prepared in $0.01 \%(\mathrm{v} / \mathrm{v})$ Triton $\mathrm{X}-100$ and $6 \mathrm{~h}$ later inoculated with $C$. gloeosporioides spores. Control plants were sprayed with $0.01 \%(v / v)$ Triton X-100 and 6 h later also inoculated with the fungus. The mock- inoculated plants were treated with Milli-Q grade water. Error bars represent standard deviation. Asterisk (*) indicates significant differences between treatment and control, calculated by the Tukey's test at a $5 \%$ confidence level (p $\leq 0.05)$. Grading scale: $0=$ no symptom; $1=0$ to $20 \%$ disease severity; $2=20$ to $40 \%$ disease severity; $3=40$ to $60 \%$ disease severity; $4=60$ to $80 \%$ disease severity; $5=$ 80 to $100 \%$ disease severity.

C. gloeosporioides (Fig. 4). Enhanced defense responses and reduction of disease symptoms have been reported for other carbohydrate elicitors such as the yeast saccharide (Yu et al., 2012), oligo-carrageenans (Vera et al., 2012), and chitosan (Chen et al., 2014) among others. Sangha et al., (2011) showed that carrageenans have differential effects on Arabidopsis resistance to Trichoplusia ni and that the degree of sulfation of the polysaccharide chain mediates this effect. Recently, it was reported that application of ulvan, a water-soluble polysaccharide from green seaweeds, in bean (Phaseolus vulgaris) leaves was effective in reducing locally and systemically the anthracnose severity in a Colletotrichum lindemuthianum susceptible genotype (Freitas and Stadnik, 2012).

In our work, SPLSAp sprayed alone at 100 and $200 \mathrm{mg} \mathrm{L}^{-1}$ concentrations (Fig. 1) and in combination with C. gloeosporioides inoculation (Fig. 2) induced considerable increases in the leaf POX activity of cowpea plants. POX are well studied enzymes in plant/pathogen interaction. They participate in the reaction of $\mathrm{H}_{2} \mathrm{O}_{2}$ dependant polymerization of hydroxycinnamyl alcohols for lignin biosynthesis and deposition that reinforce the plant cell wall(Voxeur et al., 2015) in opposition to the entry of pathogens. Increased POX activity 
in plant tissues can arise from the contact with pathogens, mechanical damages, and chemicals, which distinguish this enzyme as a marker of resistance. Recently, Nikraftar et al. (2013) demonstrated that the resistance of tomato cultivars to Rhizoctonia solani isolates is related to antioxidant defense mechanisms that involve APX and POX. The data presented in our work showed increased POX activity in the cowpea leaves after SPLSAp treatment (Fig. 1), particularly at 200 $\mathrm{mg} \mathrm{L}^{-1}$ concentration. The POX activity was even higher when the SPLS $A p$ treatment (100 and $200 \mathrm{mg} \mathrm{L}^{-1}$ ) was combined with $C$. gloeosporioides inoculation (Fig. 3). This suggested an added inducing effect probably by pathogen-/microbe associated molecular patterns (PAMPs/MAMPs) from C. gloeosporioides and/or damage-associated molecular patterns (DAMPs) elicitors from cowpea, which were recognized by plant pattern recognition receptors (PRRs) and triggered defense responses (Boutrot and Zipfel, 2017). The foliar spray of ulvan increased POX activity in inoculated susceptible bean (P. vulgaris) and reduced in 60 and $40 \%$ the anthracnose severity caused by $C$. lindemuthianum at the site of infection and systemically, (Freitas and Stadnik, 2012). Previously, we have noticed, in a time-course study, association of a rapid increase in the PR-protein POX activity during an incompatible interactions of a cowpea genotype (TE 97-411-1E) with C. gloeosporioides (Oliveira et al., 2013).

Another important enzyme that participates in the process of plant defense is APX, which is involved in the response to oxidative stress. Increased activity of APX in response to different stresses has been previously reported (Zeng et al., 2010; Jindrichová et al., 2011). In our work, SPLSAp sprayed in combination with $C$. gloeosporioides inoculation induced considerable increases in the leaf APX activity of the cowpea plants (Fig. 2). The foliar spray of Artemisia annua with chitosan induced a peak of APX activity and other enzymes related to plant defense, $24 \mathrm{~h}$ after application (Lei et al., 2011). For instance, one of the main events that occur at the onset of plant pathogen infection is the generation of ROS, particularly hydrogen peroxide $\left(\mathrm{H}_{2} \mathrm{O}_{2}\right.$ ) (Waszczak et al., 2018). Accumulation of free radicals after pathogen attack can cause oxidative damage, deregulation of several metabolic pathways and physiological processes (Foyer and Noctor, 2016). Therefore, antioxidant enzymes as APX have fundamental roles in the establishment of cell homeostasis and prevention of plant cell death, which could favor the necrotrophic stage of the $C$. gloeosporioides life cycle (Elloy et al., 2015). Actually, APX is considered one of the most important $\mathrm{H}_{2} \mathrm{O}_{2}$-scavenging enzymes in the chloroplasts and cytosol. During reaction, APX uses ascorbate as a reducing agent, which is regenerated through the glutathione-ascorbate cycle (Waszczak et al., 2018). Zeng et al. (2010) suggested that chitosan treatment could induce disease resistance in navel orange (Citrus sinensis) fruit by regulating the $\mathrm{H}_{2} \mathrm{O}_{2}$ levels, antioxidant enzyme and ascorbate-glutathione cycle.

$\beta G L U$ activity also increased when the cowpea leaves were treated with SPLSAp (Fig. 2). Similarly, to POX and APX activity, cowpea plants pre-treated with SPLSAp and $6 \mathrm{~h}$ later inoculated with C. gloeosporioides showed higher increases in $\beta G L U$ activity (Fig. 3) in comparison with plants that received solely the SPLSAp spray (Fig. 2). Elicitor-inducing effects of SPLS $A p$ together with recognition of MAMPs/PAMps from C. gloeosporioides and/or DAMPs from cowpea by PRRs (Boutrot and Zipfel, 2017) might have contributed to this higher $\beta$ GLU response. $\beta$ GLU belongs to the PR-2 family of PR-proteins and catalyzes the breakdown of endo- $\beta$-1,3-glycolytic bonds present in $\beta$-1,3-glucans, abundant in the cell wall of fungi (Feofilova, 2010). Usually, the $\beta$ GLU content is low in healthy plants. However, in pathogen infected plants or in elicitor induced plants $\beta$ GLU activity increases rapidly and, in general, this implies that the Systemic Acquired Resistance (SAR) was established since induction of this PR-protein is a marker of active defense (Bargabus et al., 2004).

In relation to $\mathrm{CHI}$, increased activity in cowpea leaves treated with SPLSAp at both concentrations (100 and $200 \mathrm{mg} \mathrm{L}^{-1}$ ) (Fig. 2) was noticed soon after $12 \mathrm{~h}$ exposition. In the group of plants pre-treated with SPLSAp and post-inoculated with $C$. gloeosporioides, there was also a significant increase in $\mathrm{CHI}$ activity in relation to control plants, but at the first hours $(6-12 \mathrm{~h})$ after the SPLSAp treatment (Fig. 3). This earlier induction in the combined treatments compared with the treatment of plants solely with SPLSAp without fungal post-inoculation might also be an added inducing effect of MAMPs/PAMps from C. gloeosporioides and/or DAMPs from cowpea (Boutrot and Zipfel, 2017) that led to a more quickly response to the fungal aggression. For instance, PR-proteins are well defined as proteins that are induced by pathogens and elicitors (Van Loon et al., 2006; Boutrot and Zipfel, 2017). $\beta \mathrm{GLU}$ and CHI are believed to contribute to plant defense in two ways. Directly, by degrading the $\beta$-1,3-glucan and chitin, respectively, from the fungal cell walls and destroying the pathogenic organisms integrity, or indirectly by releasing elicitor-active oligosaccharide from the fungal cell wall (Ji and Kuć, 1996). These released elicitors can be detected by receptors of the host plant where they trigger gene activation, production of antimicrobial compounds, and possibly Programmed Cell Death (PCD) that led to both local and systemic disease resistance (Gururania et al., 2012). Indeed, PR-proteins such as $\beta$ GLU and CHI have been shown to be associated with induced resistance to pathogens (Falcón-Rodríguez et al., 2011; Caillot et al., 2012). For example, transgenic plants expressing one or more PR-proteins showed enhanced resistance to infection 
A sulfated derivative galactomannan from Adenanthera pavonina seeds elicits defense-related responses in cowpea

by fungi (Kishimoto et al., 2002; Wang et al., 2003; O'Kennedy et al., 2011).

The necrotic lesions presented in the primary leaves of cowpea inoculated with C. gloeosporioides were large in size and numerous and spread along the entire leaf blade (Fig. 4), resembling the typical lesions of anthracnose (bronze-colored to brown, circular, deepened, and moistened) as reported for other cowpea varieties (Bailey et al., 1990). However, the plants previously treated with SPLSAp and next inoculated with $C$. gloeosporioides showed weak disease severity with lesions reduced in size and quantity, mainly in the cowpea plants treated with the highest carbohydrate concentration $\left(200 \mathrm{mg} \mathrm{L}^{-1}\right)$. This means that the pre-treatment with SPLSA $A p$ enhanced resistance of cowpea to anthracnose (Fig 5). Importantly, we found that SPLSAp had no in vitro deleterious effects on the germination or mycelial growth of C. gloeosporioides. Good defense response inducers are those devoid of direct fungicidal action per si (Terry and Joyce 2004; Bautista-Baños et al., 2006; Zhang et al., 2013). This trait for elicitors is advantageous because they do not act directly on non-target organisms holding exciting promise for their application in agriculture. However, for SPLA $A p$ to become commercially acceptable and available several questions have to be addressed (Favel, 2005): (a) does SPLA $A p$ control anthracnose under field conditions? (b) is SPLA $A p$ effective alone or it has to be combined with biological chemicals or biological control agents?; (c) is the cost of SPLAAp production compatible with an efficient induction of resistance?; (d) is SPLAAp effective to be used in multiple locations and seasons?; (e) is the large scale production of SPLA $A p$ limited by the restrictive number of seeds available to extract its precursor galactomannans?; (f) as a product, how long it can be stored for commercialization?. In summary, many challenges need to be overcome before SPLA $A p$ becomes an alternative elicitor of direct plant defence reactions.

In conclusion, the chemically sulfated derivative galactomannan (SPLSAp) produced from the naturally occurring galactomannan of $A$. pavonina seeds has the potential to be used as an elicitor toward enhancing cowpea resistance to anthracnose. SPLSAp induced cowpea defense reactions by changing the kinetic patterns of some PR-proteins and increasing the tolerance of cowpea against the fungus $C$. gloeosporioides. Thus, SPLSAp constitutes an elicitor that may be recognized by receptors of the cowpea cells and lead to molecular events that trigger plant defense reactions. Accordingly, SPLSAp merits further investigation as a promising alternative or supplemental environmentally friendly elicitor to protect cowpea against anthracnose.

\section{ACKNOWLEDGMENTS}

This work was financially supported by the Council for Advanced Professional Training (CAPES), the National Council for Scientific and Technological Development (CNPq, grant 308107/2013-6), the Scientific and Technological Development Support Program (PADCT), and the Research Council of the State of Ceara (FUNCAP, grant 2155/PRONEX). CAPES sponsored Anna L. N. Varela with a MS grant.

\section{AUTHOR CONTRIBUTIONS}

All authors contribute equally with this manuscript.

\section{REFERENCES}

Ara A, Saleh-e-In MM, Ahmed NU, Ahmed M, Hashem MAH, Bachar SC. 2010. Phytochemical screening, analgesic, antimicrobial and anti-oxidant activities of bark extracts of Adenanthera pavonina (Fabaceae). $A d v$ Nat Appl Sci. 4: 352-360. https://doi.org/10.7439/ijbr. $\mathrm{v} 2 \mathrm{i} 2.85$

Bailey JA, Nash C, O'Connell RJ. 1990. Infection process and host specificity of a Colletofrichum species causing anthracnose disease of cowpea, Vigna unguiculata. Mycology. 94: 810-814. https://doi.org/10.1016/S09537562(09)81382-8

Bargabus RL, Zidack NK, Sherwood JE, Jacobsen BJ. 2004. Screening for the identification of potential biological control agents that induce systemic acquired resistance in sugar beet. Biol Control 30: 342-350. https://doi. org/10.1016/j.biocontrol.2003.11.005

Bautista-Baños S, Hernández-Lauzardo AN, Velázques-Del Valle MG, Hernández-López M, Barka EA, BosquezMolina E, Wilson CL. 2006. Chitosan as a potential natural compound to control pre and postharvest diseases of horticultural commodities. Crop Prot. 25:108-118. https://doi.org/10.1016/j.cropro.2005.03.010

Boller T. 1992. Biochemical analysis of chitinase and $\beta$-1,3-glucanases. Pp. 23-30. In: Gurr SJ, McPherson MJ, Bowles DJ, (Eds.). Molecular Plant Pathology: a Practical Approach, vol. II. New York, Oxford University Press.

Boubakri H, Wahabc MA, Chong J, Gertza C, Gandourab S, Mlikib A, Bertsch C, Soustre-Gacougnolle I. 2013. Methionine elicits $\mathrm{H}_{2} \mathrm{O}_{2}$ generation and defense gene expression in grapevine and reduces Plasmopara 
OLIVEIRA et al.

viticola infection. J Plant Physiol. 170: 1561-1568. https://doi.org/10.1016/j.jplph.2013.06.008

Boutrot F,ZipfelC. 2017. Function, discovery, and exploitation of plant pattern recognition receptors for broad-spectrum disease resistance. Annu Rev Phytopathol. 55: 257-86. https://doi.org/10.1146/annurev-phyto-080614-120106

Bradford MM. 1976. A rapid and sensitive method for quantification of micrograms quantities of protein utilizing the principle of protein-dye binding. Anal Biochem. 72: 248-254. https://doi.org/10.1016/00032697(76)90527-3

Caillot S, Rat S, Tavernier ML, Michaud P, Kovenswky J, Wadouachi A, Clément C, Baillieul F, Petit E. 2012. Native and sulfated oligoglucuronans as elicitors of defence-related responses inducing protection against Botrytis cinerea of Vitis vinifera. Carbohydr Polym. 87:1728-1736. https://doi.org/10.1016/j. carbpol.2011.09.084

Caputo HE., Straub JE., Grinstaff MW. 2019. Design, synthesis, and biomedical applications of synthetic sulphated polysaccharides. Chem Soc Rev Advance Article. https://doi.org/10.1039/C7CS00593H

Chen J, Zou X, Liu Q, Wang F, Feng W, Wan N. 2014. Combination effect of chitosan and methyl jasmonate on controlling Alternaria alternata and enhancing activity of cherry tomato fruit defense mechanisms. Crop Prot. 56: 31-36. https://doi.org/10.1016/j.cropro.2013.10.007

Eloy YRG, Vasconcelos IM, Barreto ALH, FreireFilho FR, Oliveira JTA. 2015. H2O2 plays an important role in the lifestyle of Colletotrichum gloeosporioides during interaction with cowpea [Vigna unguiculata (L.) Walp.]. Fungal Biol. 119: 747-757. https://doi.org/10.1016/j.funbio.2015.05.001

Falcón-Rodríguez AB, Costales D, Cabrera JC, Martínez-Téllez MA. 2011. Chitosan physico-chemical properties modulate defense responses and resistance in tobacco plants against the oomycete Phytophthora nicotianae. Pest Biochem Physiol. 100: 221-228. https://doi.org/10.1016/j.pestbp.2011.04.005

Fravel DR. 2005. Commercialization and implementation of biocontrol. Annu. Rev Phytopathol. 43: 337-59. https://doi.org/10.1146/annurev.phyto.43.032904.092924

Feofilova EP. 2010. The fungal cell wall: modern concepts of its composition and biological function. Microbiology 79: 711-720. https://doi.org/10.1134/ S0026261710060019
Freire FCO, Cardoso JE, Santos AA, Viana FMP. 2002. Diseases of cashew nut plants (Anacardium occidentale L.) in Brazil. Crop Prot. 21: 489 -494. https://doi.org/10.1016/S0261-2194(01)00138-7

Freitas MB, Stadnik MJ. 2012. Race-specific and ulvan-induced defense responses in bean (Phaseolus vulgaris) against Colletotrichum lindemuthianum. Physiol Mol Plant Path. 78: 8-13. https://doi. org/10.1016/j.pmpp.2011.12.004

Foyer CH, Noctor G. 2016. Stress-triggered redox signalling: what's in pROSpect?. Plant Cell Environ. 39 951-964. https://doi.org/10.1111/pce.12621

Godoi, AM, Faccin-Galhardi, LC, Lopes N, Rechenchoski, DZ, Almeida RR, Ricardo NMPS, Nozawa C, Linhares REC. 2014. Antiviral activity of sulfated polysaccharide of Adenanthera pavonina against poliovirus in Hep-2 cells. J Evid Based Complementary Altern Med. 6: 1-6. https://doi.org/10.1155/2014/712634

Gururania MA, Venkatesh J, Upadhyaya CP, Nookaraju A, Pandey SK, Park SW. 2012. Plant disease resistance genes: Current status and future directions. Physiol Mol Plant Pathol. 78: 51-65. https://doi.org/10.1016/j. pmpp.2012.01.002

Ji C, Kuć. 1996. Antifungal activity of cucumber $\beta-1,3-$ glucanase and chitinase. Phisiol Mol Plant Pathol. 49: 257-265. https://doi.org/10.1006/pmpp.1996.0053

Jindřichová B, Fodor J, Šindelářová M, Burketová L, Valentová O. 2011. Role of hydrogen peroxide and antioxidant enzymes in the interaction between a hemibiotrophic fungal pathogen, Leptosphaeria maculans, and oilseed rape. Environ Exp Bot. 72: 149-156. https://doi.org/10.1016/j.envexpbot.2011.02.018

Kadotani N, Akagi A, Takatsuji H, Miwa T, Igarashi D. 2016. Exogenous proteinogenic amino acids induce systemic resistance in rice. BMC Plant Biol. 16: 60. https://doi. org/10.1186/s12870-016-0748-x

Kishimoto K, Nishizawa Y, Tabei Y, Hibi T, Nakajima M, Akutsu K. 2002. Detailed analysis of rice chitinase gene expression in transgenic cucumber plants showing different levels of disease resistance to gray mold (Botrytis cinerea). Plant Sci. 162: 655-662. https://doi.org/10.1016/S0168-9452(01)00602-1

Koshiba T. 1993. Cytosolic ascorbate peroxidase in seedlings and leaves of maize (Zea mays). Plant Cell Physiol. 34: 713-721.https://doi.org/10.1093/oxfordjournals.pcp. a078474 
A sulfated derivative galactomannan from Adenanthera pavonina seeds elicits defense-related responses in cowpea

Lei C, Ma D, Pu G, Qiu X, Du Z, Wang H, Li G, Ye H, Liu B. 2011. Foliar application of chitosan activates artemisinin biosynthesis in Artemisia annua L. Ind Crop Prod. 33:176-182. https://doi.org/10.1016/j.indcrop.2010.10.001

Loren E, García-Agustín P, Lape-a L. 2017. Advances in induced resistance by natural compounds: towards new options for woody crop protection. Sci Agric. 74: 90-100. https://doi.org/10.1590/1678-992x-2016-0012

Mishra AK, Sharma K, Misra RS. 2012. Elicitor recognition, signal transduction and induced resistance in plants. J Plant Interact. 7: 95-120. https://doi.org/10.1080/174 29145.2011.597517

Molano J, Duram A, Cabib E. 1997. A rapid and sensitive assay for chitinase using tritiated chitin. Anal Biochem. 83: 648-656. https://doi.org/10.1016/00032697(77)90069-0

Mostafalou S, Abdollahi M. 2013. Pesticides and human cronic diseases; Evidences, mechanisms, and perspectives. Toxicol Appl Pharmacol. 268: 157-177. https://doi.org/10.1016/j.taap.2013.01.025

Nakano Y, Asada K. 1981. Hydrogen peroxide is scavenged by ascorbate-specific peroxidase in spinach chloroplasts. Plant Cell Physiol. 22: 867-880.

Newman MA, Sundelin T, Nielsen JT, Erbs G. 2013. MAMP (microbe-associated molecular pattern) triggered immunity in plants. Plant Sci. 16: 4-39. https://doi.org/10.3389/fpls.2013.00139

Nikraftar F, Taheri P, Rastegar MF, Tarighi S. 2013. Tomato partial resistance to Rhizoctonia solani involves antioxidative defense mechanisms. Physiol Mol Plant Path. 81: 74-83. https://doi.org/10.1016/j. pmpp.2012.11.004

O'Kennedy MM, Crampton BG, Breese WA, Chakauya E, Burger JT, Botha FC. 2011. Expression of a $\beta$-1,3-glucanase from a biocontrol fungus in transgenic pearl millet. S Afr J Bot. 77: 335-345. https://doi.org/10.1016/j.sajb.2010.09.016

Oliveira JTA, Barreto ALH, Vasconcelos IM, Eloy YRG, Gondim DMF, Fernandes CF, Freire-Filho FR. 2013. Role of antioxidant enzymes, hydrogen peroxide and pr-proteins in the compatible and incompatible interactions of cowpea (Vigna unguiculata) genotypes with the fungus Colletotrichum gloeosporioides. J Plant Physiol Pathol. 2: 1-8. https://doi.org/10.4172/2329-955X.1000131
Paul GC, Kent C, Thomas CR. 1992. Viability testing and characterisation of germination of fungal spores by automatic image analysis. Biotechnol Bioeng. 42:11-23. https://doi.org/10.1002/bit.260420103

Raposo MFJ, Morais RMSC Morais, Bernardo AMM. 2013. Bioactivity and applications of sulphated polysaccharides from marine microalgae. Mar Drugs 11: 233-252. https://doi.org/10.3390/md11010233

Reissig JL, Sromenger JL, Leloir LF. 1995. A modified colorimetric method for the estimation of $\mathrm{N}$-acetylamino sugars. J Biol Chem. 217: 959-966.

Sangha JS, Khan W, Ji X, Zhang J, Mills AAS, Critchley AT, Prithiviraj B. 2011 Carrageenans, sulphated polysaccharides of red sea weeds, differentially affect Arabidopsis thaliana resistance to trichoplusia ni (Cabbage looper). PLoS ONE. 6(10):e26834. https://doi.org/10.1371/journal.pone.0026834

Sels J, Mathys J, Coninck BMA, Cammue BPA, Bolle MFC. 2008. Plant pathogenesis-related (PR) proteins: A focus on PR peptides. Plant Physiol Biochem. 46: 941-950. https://doi.org/10.1016/j.plaphy.2008.06.011

Silveira JAG, Costa RCL, Oliveira JTA. 2001. Droughtinduced effects and recovery of nitrate assimilation and nodule activity in cowpea plants inoculated with Bradyrhizobium spp. under moderate nitrate level. Braz J Microbiol. 32: 187-194. https:/doi.org/10.1590/S1517-83822001000300005

Soares JR, de Carvalho AQ, Dos Santos IS, Machado OLT, Vasconcelos IM, Ferreira ATS, Perales J, Gomes VM. 2012 Antimicrobial peptides from Adenanthera pavonina L. Seeds: characterization and antifungal activity. Protein Pept Lett. 19: 520-529. https://doi.org/10.2174/092986612800191062

Suryanto D, Wahyuni S, Siregar EBM, Munir E. 2014. Utilization of chitinolytic bacterial isolates to control anthracnose of cocoa leaf caused by Colletotrichum gloeosporioides. Afr J Biotechnol. (15):1631-1637. https://doi.org/10.5897/AJB11.3687

Terry LA, Joyce DC. 2004. Elicitors of induced disease resistance in postharvest horticultural crops: a brief review. Postharvest Biol Technol. 33: 1-13. https://doi.org/10.1016/j.postharvbio.2003.09.016

Thakur M, Sohal BS. 2013. Role of elicitors in inducing resistance in plants against pathogen infection - A review. ISRN Biochemistry. Article ID 762412, 1-10. https://doi.org/10.1155/2013/762412 
Trouvelot S, Héloir M-C, Poinssot B, Gauthier A, Paris F, Guillier C, Combier M, Trdá L, Daire X, Adrian M. 2014. Carbohydrates in plant immunity and plant protection: roles and potential application as foliar sprays. Front Plant Sci. 5: Article 592. https://doi.org/10.3389/fpls.2014.00592

Urbanek H, Kuzniak-Gebarowska E, Herka K. 1991. Elicitation of defense responses in bean leaves by Botrytis cinerea polygalacturonase. Acta Physiol Plant. 13: 43-50.

Van Loon LC, Rep M, Pierterse CMJ. 2006. Significance of inducible defense-related proteins in infected plants. Annu Rev Phytopathol. 44: 135-162. https://doi. org/10.1146/annurev.phyto.44.070505.143425

Vera J, Castro J, Contreras RA, González A, Moenne A. 2012. Oligo-carrageenans induce a long-term and broad-range protection against pathogens in tobacco plants (var. Xanthi). Physiol Mol Plant Path. 79: 31-39. https://doi.org/10.1016/j.pmpp.2012.03.005

Vieira IGP, Mendes FNP, Galão MI, Brito ES. 2007. NMR study of galactomannans from the seeds of mesquite tree (Prosopis juliflora (Sw) DC). Food Chem. 101: 70-73. https://doi.org/10.1016/j.foodchem.2005.11.052

Voxeur A, Wang Y, Sibout R. 2015. Lignification: different mechanisms for a versatile polymer. Curr Opin Plant Biol. 23: 83-90. https://doi.org/10.1016/j. pbi.2014.11.006
Wang W, Vinocur B, Altman A. 2003. Plant responses to drought, salinity and extreme temperatures: toward genetic engineering for stress tolerance. Planta 218: 1-14. https://doi.org/10.1007/s00425-003-1105-5

Waszczak C., Carmody M, Kangasjarvi J. 2018. Reactive oxygen species in plant signaling. Annu Rev Plant Biol. 69: 209-36. https://doi.org/10.1146/ annurev-arplant-042817-040322

Wiesel L., Newton AC., Elliott I, Booty D., Gilroy EM, Birch P RJ, Hein I. 2014. Molecular effects of resistance elicitors from biological origin and their potential for crop protection. Front Plant Sci. 5: article 655. https://doi.org/10.3389/fpls.2014.00655

Yu Q, Chen Q, Chen Z, Xu H, Fu M, Li S, Wang H, Xu M. 2012. Activating defense responses and reducing postharvest blue mold decay caused by Penicillium expansum in peach fruit by yeast saccharide. Postharvest Biol Technol. 74: 100-107. https://doi.org/10.1016/j. postharvbio.2012.07.005

Zeng K, Deng Y, Ming J, Deng L. 2010. Induction of disease resistance and ROS metabolism in navel oranges by chitosan. Scientia Horticulturae 126: 223-228. https://doi.org/10.1016/j.scienta.2010.07.017

Zhang Z, Yang D, Yang B, Gao Z, Li M, Jiang Y, Hu M. 2013. $\beta$-Amonobutyric acid induces resistance of mango fruit to postharvest anthracnose caused by Colletotrichum gloeosporioides and enhances activity of fruit defense mechanisms. Sci Hort. 160: 78-84. https://doi.org/10.1016/j.scienta.2013.05.023 